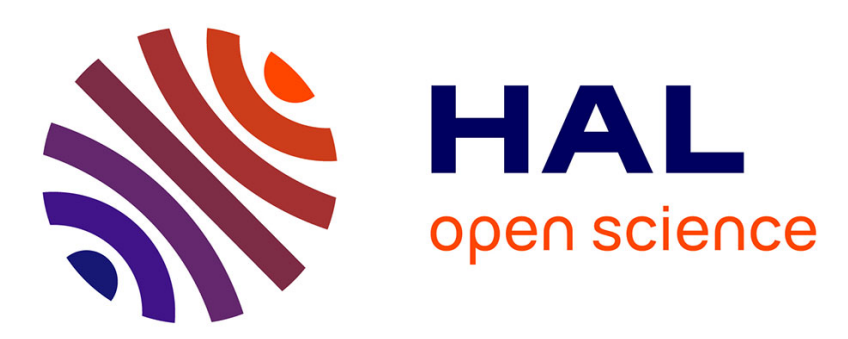

\title{
Agronomic comparison of two sets of SSD barley lines differing for the ym4 resistance gene against barley mosaic viruses
}

Jacques Le Gouis, Louis Jestin, Frank Ordon, Denis de Froidmont, Denis Béghin, Jean-Louis Joseph, Fernand Froidmont

\section{To cite this version:}

Jacques Le Gouis, Louis Jestin, Frank Ordon, Denis de Froidmont, Denis Béghin, et al.. Agronomic comparison of two sets of SSD barley lines differing for the ym4 resistance gene against barley mosaic viruses. Agronomie, 1999, 19 (2), pp.125-131. hal-00885920

\section{HAL Id: hal-00885920 https://hal.science/hal-00885920}

Submitted on 1 Jan 1999

HAL is a multi-disciplinary open access archive for the deposit and dissemination of scientific research documents, whether they are published or not. The documents may come from teaching and research institutions in France or abroad, or from public or private research centers.
L'archive ouverte pluridisciplinaire HAL, est destinée au dépôt et à la diffusion de documents scientifiques de niveau recherche, publiés ou non, émanant des établissements d'enseignement et de recherche français ou étrangers, des laboratoires publics ou privés. 


\title{
Agronomic comparison of two sets of SSD barley lines differing for the $y m 4$ resistance gene against barley mosaic viruses
}

\author{
Jacques Le Gouis ${ }^{\mathrm{a}^{*}}$, Louis Jestin ${ }^{\mathrm{b}}$, Frank Ordon ${ }^{\mathrm{c}}$, Denis de Froidmont ${ }^{\mathrm{d}}$, Denis Béghin ${ }^{\mathrm{a}}$, \\ Jean-Louis Joseph ${ }^{\mathrm{b}}$, Fernand Froidmont ${ }^{\mathrm{d}}$ \\ ${ }^{a}$ Laboratoire d'amélioration des plantes, Inra, Domaine de Brunehaut, 80200 Estrées-Mons, France \\ ${ }^{\mathrm{b}}$ Laboratoire d'amélioration des plantes, Inra, Domaine de Crouelle, 63039 Clermont-Ferrand Cedex, France \\ c Institut für Pflanzenbau und Pflanzenzüchtung I, Justus-Liebig-Universität, Ludwigstrasse 23, 35390 Giessen, Germany \\ ${ }^{\mathrm{d}}$ Station d'amélioration des plantes, rue du Bordia 4, 5030 Gembloux, Belgium
}

(Received 8 June 1998; accepted 5 November 1998)

\begin{abstract}
The ym4 gene has been extensively used in breeding for resistance against barley mosaic viruses. The objective of this study was to investigate whether resistant lines carrying this gene were lower yielding than susceptible lines derived from the same cross when grown on a disease-free soil. Eighteen susceptible and 18 resistant F7 lines derived from a three-way cross were grown over 2 years at four locations. In four out of eight trials, susceptible lines had on average a higher yield than resistant ones by $0.25 \mathrm{t} \mathrm{ha}^{-1}(0 \%$ humidity). In one trial, resistant lines significantly outyielded susceptible ones by $0.3 \mathrm{t} \mathrm{ha}^{-1}$. In this case lodging was high and it was shown that susceptible lines were more susceptible to lodging. They also headed later $(+1.4$ days on average), were taller $(+2.8 \mathrm{~cm})$ and generally had a higher thousand kernel weight than resistant lines. Effect of the $y m 4$ gene cannot easily be separated from possible effect of linked genes but this study clearly showed that selecting for $y m 4$ can lead to indirect selection of unfavourable traits. (@ Inra/Elsevier, Paris.)
\end{abstract}

Hordeum vulgare / barley yellow mosaic virus / ym4 resistance gene

Résumé - Comparaison agronomique de deux séries de lignées d'orge obtenues par SSD et différant par la présence du gène ym4 de résistance aux virus de la mosaïque de l'orge. Le gène de résistance $y m 4$ a été fréquemment employé en Europe pour la création de variétés résistantes aux virus de la mosaïque de l'orge. L'objectif de ce travail était d'étudier si des lignées résistantes portant ce gène montraient un rendement plus faible en l'absence de la maladie que des lignées sensibles issues du même croisement. Pour cela 18 lignées F7 sensibles et 18 résistantes tirées d'un croisement triple ont été cultivées pendant 2 ans en quatre lieux. Dans quatre essais sur huit, les lignées sensibles ont

Communicated by Robert Koebner (Norwich, UK)

* Correspondence and reprints

E-mail: legouis@mons.inra.fr 
obtenu en moyenne un rendement supérieur de $0,25 \mathrm{tha}^{-1}(0 \%$ d'humidité) à celui des lignées résistantes. Dans un des essais, les lignées résistantes avaient un rendement significativement supérieur de $0,3 \mathrm{t} \mathrm{ha}^{-1}$. Dans ce cas, la verse était élevée et il a été montré que les lignées sensibles aux virus étaient plus sensibles à la verse. Elles étaient aussi plus tardives à l'épiaison $(+1,4 \mathrm{j}$ en moyenne), plus hautes $(+2,8 \mathrm{~cm})$ et avaient généralement un poids de mille grains supérieur. L'effet du gène ym 4 peut difficilement être séparé de gènes qui lui seraient liés mais cette étude prouve qu'en sélectionnant pour la résistance des caractères défavorables peuvent être aussi sélectionnés. (৫ Inra/Elsevier, Paris).

\section{Hordeum vulgare / virus de la mosaïque de l'orge / gène de résistance ym4}

\section{INTRODUCTION}

Barley yellow mosaic virus (BaYMV) and barley mild mosaic virus (BaMMV) were described for the first time in Europe in the late 1970s [11]. These viruses are transmitted by the soil-borne fungus Polymyxa graminis Led. [20]. Since the first report of the disease plant breeders have bred for resistant barley (Hordeum vulgare L.) varieties. Friedt et al. [4] have shown that the resistance commonly used in Europe was caused by one gene later named ym4 [5]. Huth [9] has traced back its probable origin to the Dalmatian landrace Ragusa. The $y m 4$ gene confers resistance to BaMMV and the first reported strain of BaYMV (BaYMV-1) but is not effective against a second strain of BaYMV (BaYMV-2) found in the late 1980s [3, 10]. On a field infected with BaMMV and BaYMV-1, cultivars carrying the $y m 4$ gene have been shown to outyield susceptible cultivars by about $40 \%$ [16]. During selection work, it has, however, been observed that susceptible lines seemed to be generally higher yielding than resistant lines derived from the same cross and grown on a disease-free soil. Effects of resistance genes under disease-free conditions have already been reported. In comparison with the susceptible recurrent parent, an overall $4 \%$ yield reduction was reported for stem rust (Puccinia graminis Pers. f. sp. tritici Eriks. \& Henn.) resistant near-isogenic lines of winter wheat (Tricticum aestivum) [18]. Knott [14] also measured differences for grain yield, heading dates, days to maturity, plant height and lodging with different sets of near-isogenic lines. There appeared to be a tendency for resistance genes to reduce yield but these effects varied depending on diversity of genes and environments tested. Ortelli et al. [17] reported also a $12 \%$ yield reduction associated with a $6 \%$ reduction in grain number for leaf rust (Puccinia recondita Rob. ex Desm. f. sp. tritici) resistant near-isogenic lines of winter wheat. The objective of this study was then to investigate the effect of selection for the $y m 4$ gene in the absence of the pathogen.

\section{MATERIAL AND METHODS}

Friberga and Plaisant are two six-rowed winter barley cultivars susceptible to barley mosaic viruses. Thalassa is a six-rowed winter barley resistant to BaMMV and BaYMV-1 and is supposed to carry the $y m 4$ gene, as do all other French resistant cultivars. Non-selected single seed descent (SSD) progenies were derived in virus-free conditions from the three-way cross Thalassa // Friberga / Plaisant. The cross was performed in 1990 at ClermontFerrand and the F' 1 was raised at DSIR, Christchurch (New Zealand), in a 1990-1991 off-season. Further generations, from $\mathrm{F} 2$ to $\mathrm{F} 6$, were sown at Clermont-Ferrand from 1991 to 1995 , one single ear being sown as a row to form the next generation. From F4 to F6, 1993 to 1995, a parallel sowing of all or part of the progenies was grown at Avail (France) in BaYMV-1 and BaYMMV highly contaminated soil. In addition, F5 progenies were partly tested in 1994 at Gembloux (Belgium) on a field infected with BaMMV and BaYMV-1 and by mechanical inoculation with BaMMV in Giessen (Germany). At the F6 stage it was thus possible to determine which families, from the total of 93 progenies considered from $\mathrm{F} 4$, were homozygous for resistance or susceptibility, and which small number of others were still segregating, or giving unclear results. Thus, 18 homozygously resistant and as many homozygously susceptible progenies were sorted out randomly among F6. Bulk-harvested seed of each family were used in the present study as F7 and then F8. 
Trials were conducted in 1996 and 1997 at four locations as random complete block designs. Main characteristics of trials are given in table I. In 1997 at Mons and Gembloux, two trials called treated (T) and non-treated (NT), differentiated by the $\mathrm{N}$ level and the use of fungicides and growth regulator were grown. Trials were located on soils chosen to be non-infected by barley mosaic viruses. Two of the progenitors, Thalassa and Plaisant, and the cultivar Express were sown as controls along with a fourth cultivar depending on the location or year: Jana in Giessen, Krimhild in Gembloux, Alaska in Clermont in 1996 and Majestic in Clermont in 1997 and in Mons. Grain yield ( $\mathrm{t} \mathrm{ha}^{-1}$ at $0 \%$ water content) and heading dates (days) were measured on all trials. The following traits were measured depending on the location and the year (tables $I I$ and $I I I$ ): thousand kernel weight $(\mathrm{TKW})$, plant height, lodging score $(1=$ no lodging, $9=$ fully lodged), cold damage $(1=$ no damage, $9=$ fully destroyed), powdery mildew (Erysiphe graminis $\mathrm{f}$. $\mathrm{sp}$. hordei) $(1=$ no symptoms, 9 = fully diseased $)$, net blotch (Drechslera teres $\mathrm{f}$. sp. teres) $(1=$ no symptoms, $9=$ fully diseased) and scald (Rhynchosporium secalis) $(1=$ no symptoms, 9 = fully diseased). Grain $\mathrm{N}$ content was measured at Mons with a near infrared reflectance analyser (Technicon InfraAlyser 400, Technicon Instrument Corporation, Tarytown, New York, USA).

Analyses of variance were first carried out for each trial with genotypes and repetition as fixed factors. Comparisons between genotypes were made using a Newman and Keuls test. Parents and controls were then excluded and analyses of variance were carried out for each trial with virus reaction (susceptible or resistant), genotype hierarchised to virus reaction and repetition as fixed factors. Means of susceptible and resistant lines for

Table I. Main characteristics of barley trials carried out in 1996 and 1997.

\begin{tabular}{|c|c|c|c|c|c|c|c|}
\hline Trial & $\begin{array}{c}\text { Sowing } \\
\text { date }\end{array}$ & $\begin{array}{l}\text { Number of } \\
\text { replications }\end{array}$ & $\begin{array}{l}\text { Plot } \\
\text { size } \\
\left(\mathrm{m}^{2}\right)\end{array}$ & $\begin{array}{c}\text { Sowing } \\
\text { density } \\
(\text { kernel/m²) }\end{array}$ & $\begin{array}{l}\mathrm{N} \\
\text { fertiliser } \\
\left(\mathrm{kg} \mathrm{ha}^{-1}\right)\end{array}$ & Fungicide & Growth regulator \\
\hline Clermont 96 & 18.10 .95 & 3 & 4.8 & 180 & 0 & 2.8 & $\begin{array}{c}2.8 \mathrm{~L} \mathrm{ha}^{-1} \text { Terpal (Mepiquat } \\
\text { chlorid } 305 \mathrm{~g} \mathrm{~L}^{-1}+ \\
\text { Etephon } 155 \mathrm{~g} \mathrm{~L}^{-1} \text { ) }\end{array}$ \\
\hline Clermont 97 & 22.10 .96 & 3 & 4.8 & 180 & 0 & no & no \\
\hline Gembloux 96 & 03.10 .95 & 4 & 4.6 & 250 & 100 & $\begin{array}{c}1.5 \mathrm{~L} \mathrm{ha}^{-1} \text { Opus Team } \\
\text { (Fenpropimorph } 250 \mathrm{~g} \mathrm{~L}^{-1}+ \\
\text { Epoxyconazol } 84 \mathrm{~g} \mathrm{~L}^{-1} \text { ) }\end{array}$ & $\begin{array}{l}0.8 \mathrm{~L} \mathrm{ha}^{-1} \text { Cérone } \\
\text { (Etephon } 480 \mathrm{~g} \mathrm{~L}^{-1} \text { ) }\end{array}$ \\
\hline Gembloux NT97 & 725.09 .96 & 2 & 4.6 & 300 & 110 & no & no \\
\hline Gembloux T 97 & 25.09 .96 & 2 & 4.6 & 300 & $\begin{array}{l}150 \\
(\mathrm{r} \\
+\end{array}$ & $\begin{array}{l}1.0 \mathrm{~L} \mathrm{ha}^{-1} \text { Allegro } \\
\text { (Kresoxim-methyl } 125 \mathrm{~g} \mathrm{~L}^{-1} \\
+ \text { Epoxyconazol } 125 \mathrm{~g} \mathrm{~L}^{-1} \text { ) }\end{array}$ & $0.8 \mathrm{~L} \mathrm{ha}^{-1}$ Cérone \\
\hline Giessen 96 & 18.09 .95 & 3 & 6.0 & 350 & 165 & $1.5 \mathrm{~L} \mathrm{ha}^{-1}$ Opus Team & $2.0 \mathrm{~L} \mathrm{ha}^{-1}$ Terpal \\
\hline Giessen 97 & 18.09 .96 & 3 & 6.0 & 350 & 94 & $\begin{array}{c}1.5 \mathrm{~L} \mathrm{ha}^{-1} \text { Opus Team }+ \\
300 \mathrm{~g} \mathrm{ha}^{-1} \text { Triticol WDG } \\
(\text { Carbendazim } 60 \%)\end{array}$ & $\begin{array}{c}1.5 \mathrm{~L} \mathrm{ha}^{-1} \text { Terpal C } \\
\text { (Chlormequat chlorid } \\
305 \mathrm{~g} \mathrm{~L}^{-1}+ \\
\text { Etephon } 155 \mathrm{~g} \mathrm{~L}^{-1} \text { ) }\end{array}$ \\
\hline Mons 96 & 10.10 .95 & 3 & 6.5 & 280 & 150 & $\begin{array}{l}1 \mathrm{~L} \mathrm{ha}^{-1} \text { Opus } \\
\text { (Epoxyconazol } \\
125 \mathrm{~g} \mathrm{~L}^{-1} \text { ) }\end{array}$ & $\begin{array}{c}1.5 \mathrm{~L} \mathrm{ha}^{-1} \text { Vivax L } \\
\text { (Chlormequat chlorid } \\
305 \mathrm{~g} \mathrm{~L}^{-1}+ \\
\left.\text { Etephon } 150 \mathrm{~g} \mathrm{~L}^{-1}\right) \\
0.75 \mathrm{~L} \mathrm{ha}^{-1} \text { Etheverse } \\
\left(\text { Etephon } 480 \mathrm{~g} \mathrm{~L}^{-1} \text { ) }\right.\end{array}$ \\
\hline Mons NT 97 & 03.10 .96 & 3 & 6.5 & 280 & 50 & no & no \\
\hline Mons T 97 & 03.10 .96 & 3 & 6.5 & 280 & 100 & $\begin{array}{l}0.5 \mathrm{~kg} \mathrm{ha}^{-1} \text { Unix } \\
\text { (Cyprodinil } 75 \%)+ \\
0.4 \mathrm{~L} \mathrm{ha}^{-1} \text { Opus } \\
1 \mathrm{~L} \mathrm{ha}^{-1} \text { Opus }\end{array}$ & $\begin{array}{l}0.6 \mathrm{~L} \mathrm{ha}^{-1} \text { Moddus } \\
\text { (Trinexapac-ethyl } \\
250 \mathrm{~g} \mathrm{~L}^{-1} \text { ) }\end{array}$ \\
\hline
\end{tabular}


Table II. Coefficient of variation for grain yield and comparison of mean values for susceptible (left) and resistant (right) lines for traits measured on the three locations in 1996. The sign $=$ indicates no significant difference at the $5 \%$ level whereas $>$ or $<$ indicate a significant difference.

\begin{tabular}{lccc}
\hline & Clermont & Giessen & Mons \\
\hline Coefficient of variation $(\%)$ & 8.4 & 4.4 & 5.9 \\
Grain yield $\left(\mathrm{t}\right.$ ha $\left.{ }^{-1}\right)$ & $7.56<7.86$ & $8.37>8.21$ & $8.27>8.01$ \\
Heading date $($ days $)$ & $132.8>131.9$ & $143.3=142.8^{1}$ & $138.7>137.8$ \\
Plant height $(\mathrm{cm})$ & $107.5>106.2$ & $104.5>101.8$ & $38.0=38.1$ \\
TKW $(\mathrm{g})$ & & $42.0<45.0$ & $1.96<2.00$ \\
N Content $(\%)$ & $4.4>3.3$ & & \\
Lodging & $3.1>2.6$ & & \\
Powdery mildew & & $5.2=4.8^{1}$ & \\
Net blotch & & & \\
\hline
\end{tabular}

${ }^{1}$ Measured on one repetition only.

Table III. Coefficient of variation for grain yield and comparison of mean values for susceptible (left) and resistant (right) barley lines to barley mosaic viruses for traits measured on four locations in 1997. The sign = indicates no significant difference at the $5 \%$ level whereas $>$ or $<$ indicate a significant difference.

\begin{tabular}{|c|c|c|c|c|c|}
\hline & Clermont & Gembloux NT & Gembloux $\mathrm{T}$ & Mons NT & Mons T \\
\hline Coefficient of variation (\%) & 6.8 & 4.6 & 6.3 & 6.8 & 4.6 \\
\hline Grain yield $\left(t \mathrm{ha}^{-1}\right)$ & $6.07=6.03$ & $6.63=6.60$ & $7.38=7.14$ & $4.61>4.26$ & $6.03>5.80$ \\
\hline Heading date (days) & $132.1>125.9$ & $134.9=134.5^{1}$ & $136.7=136.1^{1}$ & $133.6>132.8$ & $134.3>133.6$ \\
\hline Plant height $(\mathrm{cm})$ & $72.4>71.1$ & & & $112.2>108.1$ & $112.1>107.7$ \\
\hline TKW $(\mathrm{g})$ & $43.5<46.0$ & & $38.7=39.9^{1}$ & $35.4<36.6$ & $36.0<37.3$ \\
\hline $\mathrm{N}$ content $(\%)$ & & & & $1.61=160$ & $1.61=1.61$ \\
\hline Lodging & & $5.8=5.4^{1}$ & & $2.4>1.5$ & $2.4>1.5$ \\
\hline Cold & $4.2=4.1$ & & & $2.1=2.1$ & $2.0=2.0$ \\
\hline Powdery mildew & & $1.3=1.1^{1}$ & & & \\
\hline Net blotch & & $5.2=5.2^{1}$ & & & \\
\hline Scald & & $2.3=1.6^{1}$ & & & \\
\hline
\end{tabular}

${ }^{1}$ Measured on one repetition only.

traits measured on one repetition only were compared using a $t$-test. Correlation coefficients between variables were calculated on genotype means for each individual trial.

\section{RESULTS}

Results from Gembloux in 1996 and Giessen in 1997 were excluded. In Gembloux, the trial suffered from a severe early drought which resulted in low mean yield ( $\left.5.53 \mathrm{t} \mathrm{ha}^{-1}\right)$ and high experimental error (coefficient of variation $=11.4 \%$ ). The field in Giessen was revealed to be infected by BaMMV and BaYMV-1. In these conditions resistant lines logically outyielded susceptible lines by $1.13 \mathrm{tha}^{-1}$ on average.

When considering the full multisite design in a single hierarchical variance analysis model, a significant $\mathrm{F}=9.12(P=0.003)$ was obtained for the resistant versus susceptible contrast for grain yield. 
Interpretation of main effects was, however, complicated by a significant genotype $\times$ environment interaction. Results are therefore presented on a trial basis. Comparison of susceptible and resistant lines are presented in tables $I I$ and $I I I$. In four out of eight trials, susceptible lines were on average higher yielding than resistant one: Mons 96, Giessen 96, Mons NT 97 and Mons T 97. The mean difference was $0.25 \mathrm{t} \mathrm{ha}^{-1}$. In three trials no significant difference existed between susceptible and resistant lines: Clermont 97, Gembloux NT 97 and Gembloux $\mathrm{T}$ 97. In Clermont 96 resistant lines significantly outyielded susceptible lines by $0.3 \mathrm{tha}^{-1}$. In seven out of eight trials, the best susceptible and the best resistant lines were not significantly different. In Mons T 97 a susceptible line significantly outyielded all the other genotypes except Majestic. The resistant parent Thalassa significantly outyielded the susceptible parent Plaisant when averaged over all trials (6.87 and $6.39 \mathrm{t} \mathrm{ha}^{-1}$, respectively).

In all trials, susceptible lines headed later than resistant lines ( 1.4 days on average), the difference being significant in five cases. The susceptible parent Plaisant headed always earlier than the resistant parent Thalassa (132.5 and 136.3 days on average, respectively). There was a significant correlation between grain yield and heading date in Clermont 96 only $\left(-0.55^{* * *}\right)$.

Susceptible lines were significantly taller than resistant lines in all the trials where plant height was measured. The mean difference was $2.8 \mathrm{~cm}$. Plaisant was on average shorter than Thalassa $(97.8$ and $102.2 \mathrm{~cm}$ on average, respectively). Plant height was significantly correlated to heading date in four trials out of the six where they were measured: $0.56^{* * *}$ in Clermont 96, 0.41*** in Giessen 96, $0.54 * * *$ in Mons NT 97 and $0.66^{* * *}$ in Mons T 97.

Susceptible lines significantly lodged more than resistant lines in three trials out of four where lodging was scored. Except in Gembloux NT 97, Plaisant was less susceptible to lodging than Thalassa (mean lodging score of 3.2 for Plaisant and 4.5 for Thalassa). A significant negative correlation $\left(-0.69^{* * *}\right)$ existed in Clermont 96 between lodging and grain yield. In the three other trials the correlation was non-significantly different from 0 . Lodging was significantly correlated with heading date in all four trials: $0.67^{* * *}$ in Clermont 96 , $0.44^{* *}$ in Gembloux T 97, 0.52*** in Mons NT 97 and $0.46^{* *}$ in Mons $\mathrm{T} 97$. Lodging was also correlated with plant height in the trials where both variables were measured: $0.44^{* *}$ in Clermont 96 , $0.52 * * *$ in Mons NT 97 and $0.53 * * *$ in Mons T 97.

Cold damage was scored on three trials in 1997 and for all of them the difference between resistant and susceptible lines was not significant.

Resistant lines had on average a significantly higher TKW than susceptible lines in four trials out of six. The mean difference was equal to $1.6 \mathrm{~g}$. Grain N content was significantly higher for resistant lines in Mons 96. No significant differences were found in Mons in 1997. Correlations between grain $\mathrm{N}$ content and TKW were not significant. A negative correlation was shown between grain $\mathrm{N}$ content and grain yield in Mons 97 NT $(-0.44 * *)$. Thalassa had on average a significantly higher TKW than Plaisant (41.8 and 37.9, respectively).

No significant differences were found for net blotch or scald resistance in the trials where they were measured. Susceptible lines were significantly more susceptible to powdery mildew in Clermont 96. In each individual site, correlations between resistance scores to any of the diseases and TKW or grain yield were never significant.

\section{DISCUSSION}

Results reported here clearly showed that selecting for resistance to barley mosaic resistance in a three-way cross also led to the indirect selection of other traits. Susceptible lines headed later, were taller, more susceptible to lodging and had a higher TKW. Grown on a non-infected field, susceptible lines also significantly outyielded resistant lines in four trials out of eight. In one case only, resistant lines were significantly higher yielding. This latter result may be explained by lodging since a negative correlation existed between lodging and grain yield. 
The higher susceptibility to powdery mildew shown by susceptible lines is likely not to have played any role since no significant correlation existed between powdery mildew score and grain yield.

One hypothesis may be that selection for $y m 4$ had an effect on all other characters mainly through heading date. Susceptible lines headed earlier and early heading would mean shorter plants less susceptible to lodging. It would also mean fewer grains or tiller primordia and then a higher TKW because of a lower number of grains $/ \mathrm{m}^{2}$. The significant correlations between heading date and plant height may support this hypothesis. This is also the case for significant correlations between heading date and lodging or plant height and lodging. There was, however, no correlation between TKW and heading date. In addition, this hypothesis could not explain differences in grain yield, except for Clermont 96, as there was no correlation between heading date and grain yield.

The lower yield potential of resistant lines may be due to either a direct unfavourable pleiotropic effect of the resistance gene in disease-free conditions or to its linkage to undesired genes. The unfavourable effect of a resistance gene alone is difficult to demonstrate in the absence of perfect isogenic lines. Studies involving six different near isogenic lines for the $\operatorname{Lr} 9$ resistance gene against leaf rust have shown a $12 \%$ reduction in yield compared to the susceptible recurrent winter wheat parent [17]. The $L r 9$ gene comes from a wild species of wheat, Aegilops umbelullata; it is, however, possible that some unfavourable genes are tightly linked.

SSD lines derived from an F2 segregating population were used in the present design: this is clearly less powerful in testing a pleiotropic effect of the $y m 4$ gene on grain yield, than a series of backcrossed lines. Variable length of chromosome segment, carrying unfavourable genes or not, are likely to remain linked to $y m 4$. Yet it was felt that the sets of resistant and susceptible lines reflected a typical breeding situation with linkage of the selected gene to a highly variable genetic background, especially as the susceptible male gamete came from the segregation of the F1 Friberga/Plaisant.
The $y m 4$ gene is located at the end of the long arm of chromosome $3 \mathrm{H}[6,13]$. Tinker et al. [19] have searched for QTL associated with economic traits on a population of doubled haploid lines from the Harrington/TR306 cross grown in 30 environments. They reported a QTL for days to heading and plant height at the end of the chromosome $3 \mathrm{HL}$ in the region of the $y m 4$ gene $[8,21]$. They did not find a QTL for lodging, TKW, powdery mildew severity or total grain protein in the same region. Backes et al. [1, 2] did not find any QTLs for lodging, plant height, heading date or powdery mildew on chromosome $3 \mathrm{HL}$ when they studied $\mathrm{DH}$ lines from the Igri / Danilo cross. Hayes et al. [7] found QTLs for plant height, lodging, grain protein and grain yield on chromosome $3 \mathrm{HL}$ in $\mathrm{DH}$ derived from the Steptoe / Morex cross. These QTLs are, however, located at more than $40 \mathrm{cM}$ from the $y m 4$ gene. Near the EST1 locus is also located the eam10 early maturity gene [15]. Up to now no resistance genes for powdery mildew have been located on chromosome $3 \mathrm{H} \mathrm{[12].} \mathrm{The} \mathrm{size} \mathrm{of} \mathrm{the}$ mildew effect detected in our trial was, however, low indicating that no major gene was involved.

We did not test the susceptible parent Friberga along with the other genotypes. It is difficult to assess exactly its possible influence on the traits measured. Results obtained in a nursery in Clermont over 3 years showed, however, that Friberga was somewhat later flowering than Thalassa (data not shown). This may explain why susceptible lines were on average later flowering. Thalassa, a six-row feed barley registered in 1989, was higher yielding than the malting barley Plaisant registered in 1979. Friberga is a six-row feed barley registered in 1984 in former East Germany and is likely to show a good yield potential. The fact that it was possible to find in all but one trial a resistant line which had a yield similar to a susceptible line starting from a relatively small sample of lines would tend to prove that recombination can eliminate unfavourable traits. It is also possible to observe that now most of barley cultivars registered are resistant and they have high yield potential even in disease-free conditions.

Acknowledgements: We thank Dr G.C.M. Sage and W.T.B. Thomas for reviewing this manuscript. 


\section{REFERENCES}

[1] Backes G., Graner A., Foroughi-Wehr A., Fischbeck G., Wenzel G., Jahoor A., Localization of quantitative trait loci (QTL) for agronomic important characters by the use of a RFLP map in barley (Hordeum vulgare L.), Theor. Appl. Genet. 90 (1995) 294-302.

[2] Backes G., Schwarz G., Wenzel G., Jahoor A., Comparison between QTL analysis of powdery mildew resistance in barley based on detached primary leaves and on field data, Plant Breed. 115 (1996) 419-421.

[3] Beaton D., Resistant varieties hit by BYMV strain, Farmers Weekly 3 (1989) 42.

[4] Friedt W., Foroughi-Wehr B., Huth W., Züchtung auf Gelbmosaikvirus-Resistenz der Wintergerste, Vortr. Pflanzenzüchtg. 3 (1983) 169-179.

[5] Friedt W., Ordon F., Götz R., Kaiser R., Bodenbürtige Krankenheiten, eine fortdauernde Herausforderung für die Pflanzenzuichtung - beleuchtet am Beispiel der Gelbmosaikvirose der Gerste, Ber. Arbeitstag. Saatzuchtl. Gumpenstein 40 (1990) 27-38.

[6] Graner A., Bauer E., RFLP mapping of the $y m 4$ virus resistance gene in barley, Theor. Appl. Genet. 86 (1993) 689-693.

[7] Hayes P.M., Liu B.H., Knapp S.J., Chen F., Jones B., Blake T., Franckowiak J., Rasmusson D., Sorrells M., Ullrich S.E., Wesenberg D., Kleinhofs A., Quantitative trait locus effects and environmental interaction in a sample of North American barley germplasm, Theor. Appl. Genet. 87 (1993) 392-401.

[8] Hayes P.M., Chen F.Q., Kleinhofs A., Kilian A., Mather D.E., Barley genome mapping and its applications, in: Jauhar P.J. (Ed.), Methods of Genome Analysis in Plants, CRC Press, New York, 1996, pp. 229-249.

[9] Huth W., Versuche zur Virusdiagnose und Resistenzträgerstellung in Gerste gegen Barley Yellow Mosaic Virus (BaYMV), Vortr. Pflanzenzüchtg. 9 (1985) 107-120.

[10] Huth W., Ein weiterer Stamm des Barley yellow mosaic virus (BaYMV) gefunden, Nachrichtenbl. Deut. Pflanzenschutzd. 41(1989) 6-7.

[11] Huth W., Leseman D., Eine für die Bundesrepublik neue Virose an Wintergerste,
Nachrichtenbl. Deut. Pflanzenschutzd. 30 (1978) 184-185.

[12] Jahoor A., Schönfeld M., Herz M., Wenzel G., Present status of localisation of mildew resistance genes in barley and their synteny among cereals, in: Slinkard A., Scoles G., Rossnagel B. (Eds.), Proceedings of the V international oat conference and VII international barley genetics symposium, University Extension Press, University of Saskatchewan, Saskatoon, 1996, pp. 720-722.

[13] Kaiser R., Friedt W., Chromosomal location of resistance to barley yellow mosaic virus in German winter-barley identified by trisomic analysis, Theor. Appl. Genet. 77 (1989) 241-245.

[14] Knott D.R., Agronomic and quality characters of near-isogenic lines of wheat carrying genes for stem rust resistance, Euphytica 68 (1993) 33-41.

[15] Lundqvist U., Franckowiak J.D., Konishi T., New and revised descriptions of barley genes, Barley Genet. Newsl. 26 (1997) 22-516.

[16] Ordon F., Genetische Analyse der Resistenz exotischer Gersten gegen bodenbürtige, mosaikinduzierende Viren, Diss. Univ. Giessen, Verlag Shaker, Aachen, 1992.

[17] Ortelli S., Winzeler H., Winzeler M., Fried M., Nösberger J., Leaf rust gene $\operatorname{Lr} 9$ and winter wheat yield reduction: I. Yield and yield components, Crop Sci. 36 (1996) 1590-1595.

[18] The T.T., Latter B.D.H., McIntosh R.A., Ellison F.W., Brennan P.S., Fisher J., Hollamby G.J., Rathjeb A.J., Wilson R.E., Grain yields of near-isogenic lines with added genes for stem rust resistance, Proc. 7th Int. Wheat Genet. Symp. 2 (1988) 901-906.

[19] Tinker N.A., Mather D.E., The NABGMP, main effects of quantitative trait loci in Harrigton/TR306 tworow barley, Barley Genet. Newsl. 23 (1994) 72-78.

[20] Toyama A., Kusaba T., Transmission of soilborne barley yellow mosaic virus. 2. Polymyxa graminis Led. as vector, Phytopathol. Soc. Japan 36 (1970) 223-229.

[21] Weyen J., Ordon F., Friedt W., Genetic characterization of resistance against BAYMV-2, the $y m 4$ resistance breaking strain of the Barley Yellow Mosaic Virus Complex, Barley Genet. Newslett. 25 (1996) $54-56$. 